\title{
Precious metal mineralization in the East Pansky layered massif
}

\author{
A. A. Kalinin \\ Geological Institute, Kola Science Center, Russian Academy of Science, Apatity 184200, Russia \\ E-mail: kalinin@geoksc.apatity.ru
}

\begin{abstract}
Summary Three PGE mineralized zones are defined in the western and central parts of the East Pansky intrusion, the zones are controlled by the boundaries of the divisions of layering. Each zone is of complicated geological structure, it can consist of two or more mineralized horizons. These horizons are located mainly at the basement or at the upper contact of olivine-bearing rocks, or move away for dozens meters. As a rule, petrographic control of PGE mineralization is not clear, or is absent. Composition and geochemical characteristics of PGE mineralization change along the cross section of the intrusion: sulfide content decreases from $3-5 \%$ in the lower zone to zero in the upper one, and $\mathrm{Pd} / \mathrm{Pt}$ ratio decreases from $4-6$ to $<1$.
\end{abstract}

\section{Introduction}

Geological structure and PGE mineralization in the East Pansky intrusion is not studied in detail, if compared to West Pansky or Fedorova Tundra segments of the Fedorovo-Pansky layered intrusive complex. First indications of low-sulfide PGE mineralization in the East Pansky were found by JSC "Pana" in 1995-2000 during exploration of the areas Sungjok, Chuarvy, Churozersky with small volume of drilling. Mineralized zones were defined and traced along strike for more than $10 \mathrm{~km}$, and the intrusion was considered as a promising one for PGE mineralization. In 2002-2008 "Kola mining-geological company Ltd" (KMGC) carried out intense exploration for PGE in the East Pansky intrusion. As a result, the East Chuarvy deposit, the first PGE deposit in the region, and a number of ore occurrences were found (Ward et al., 2008, Kazanov, Kalinin, 2008, 2011). After 2008 there was no intense geological study in the area. The present article summarises the results of prospecting for PGE in the East Pansky intrusion in 2000s.

\section{Materials and methods}

Geological information for the article was presented by KMGC. The complex of geological study (2002-2008) included fieldwork with sampling of outcrops and boulders, drilling, logging and sampling of the drill core, assaying for PGE, $\mathrm{Cu}, \mathrm{Ni}, \mathrm{S}$. The samples were assayed in Mekhanobr Analyt in S-Petersburg.

\section{Geological structure of the East Pansky intrusion}

The East Pansky intrusion is separated from the West Pansky by the Belotundrovsky fault. The length of the East Pansky intrusion is more than $30 \mathrm{~km}$, and its thickness reaches $4.5 \mathrm{~km}$ in the central part. The intrusion is thinning in the east, and east of river Kuksha it is only a few hundred meters thick, and it can be traced farther east for another $25 \mathrm{~km}$ as minimum.

The following layers (zones) are defined in the East Pansky, from the bottom to the top: the Lower Marginal Zone (LMZ), the Gabbronorite Zone (GNZ), consisting of the lower (GNZ1) and the upper (GNZ2) subzones, and the Gabbro zone (GZ), which includes the lower (GZ1) and the upper (GZ2) subzones. Formation of each subzone was an independent stage of the intrusion development, connected with intruding of a new portion of magma. Mineral composition and cumulus associations, petrochemical and geochemical characteristics of the 
rocks change abruptly at the subzones boundaries. Rock evolution from high-temperature associations with primitive geochemical characteristics to low-temperature associations, formed of fractionated melt, enriched in non-coherent elements, can be seen within each subzone.

Steeply dipping faults of NE direction divide the East Pansky intrusions in 8 blocks, displaced for hundreds meters. Each block reveals its individual geological structure, because of different erosion level.

Bedding of the primary structural elements (contacts of the layers, trachytoidness of the rocks) is generally conformal to the lower intrusion contact, with dipping to SW 200-220 . In the lower part of the cross section, the rocks steeply dip at $70-75^{\circ}$, in the GNZ2 the dipping is $60-70^{\circ}$, and the tendency to more gentle dipping preserves farther up the cross section. Anomaly vertical, or even overturned rock bedding was found in the block of Bezymyanny.

\section{Results}

Three main zones of PGE mineralization, named A, B, and C zones, were defined in the East Pansky intrusion (Kazanov, Kalinin, 2008, 2011), the zones are controlled by the boundaries of the divisions of layering (subzones). The mineralization is of stratiform character, conformal to general layering of the intrusion, the mineralized horizons are rhythmically thin layered, the rocks contain anomaly cumulus associations (olivine, plagioclase, ensthatite-augite cumulates). Each PGE mineralized zone has specific 'stratigraphic' position, and peculiar mineral composition and geochemical characteristics $-\mathrm{Pd} / \mathrm{Pt}$ ratio.

\subsection{Mineralized zone A}

Mineralized zone A is located at the basement of GNZ1 or in the lower part of it. PGE mineralization was traced from Sungjok mountain in the west to the area of lake Churozero in the east, and includes ore occurrences Sungjok, Chuarvy, East Chuarvy. The mineralization has high $\mathrm{Pd} / \mathrm{Pt}=5-6$, and $\mathrm{Pd}$ mineral phases are frequently found in the ore. PGE content correlates with $\mathrm{S}$, but high sulphide content does not guarantee high PGE in the rock.

In the Sungjok occurrence, zone A is not outcropped, but it was drilled. Thickness of the mineralized zone varies from 0.3 to $1.7 \mathrm{~m}$, dipping is $70^{\circ}$. The best section is $\mathrm{Pt} 0.37 \mathrm{~g} / \mathrm{t}$ and $\operatorname{Pd} 2.0 \mathrm{~g} / \mathrm{t}$ for $1.7 \mathrm{~m}$.

In the Chuarvy occurrence zone A consists of 2 mineralized levels, one at the bottom, and another one at the upper contact of the olivine horizon. Thickness of the lower horizon reaches $43 \mathrm{~m}$, dipping is $75^{\circ}$ on the average. The ore zone consists of 3 ore bodies with total thickness of $7 \mathrm{~m}$, with Pt $0.769 \mathrm{~g} / \mathrm{t}$ and Pd $3.428 \mathrm{~g} / \mathrm{t}$. The upper mineralized level includes only 1 mineralized body $0.6 \mathrm{~m}$ thick with Pt $2.13 \mathrm{~g} / \mathrm{t}$ and Pd $5.12 \mathrm{~g} / \mathrm{t}$. Compared to other ore occurrences, the mineralization in the Chuarvy contains high $\mathrm{Cu} 0.25 \%$ and $\mathrm{Ni} 0.36 \%$. Chalcopyrite and pentlandite together with pyrrhotite can be visually identified in the rocks.

In the East Chuarvy mineralized zone A is located in the lower part of the horizon of the irregular grained gabbronorite (GNZ1), and partly in the underlying fine grained ensthatite gabbro in the LMZ. The rocks contain disseminated and veinlet-disseminated pyrrhotite-pyrite mineralization up to $5 \mathrm{vol} . \%$. Content of $\mathrm{Cu}$ is $0.02-0.22 \%$, Ni $0.02-0.17 \%$, S $0.04-1.77 \%$, Pt $0.12-0.28 \mathrm{~g} / \mathrm{t}, \mathrm{Pd} 0.72-1.59 \mathrm{~g} / \mathrm{t}, \mathrm{Pd} / \mathrm{Pt}$ ratio is 5.6 on the average.

\subsection{Mineralized zone $B$}

Mineralized zone B is controlled by the contact GNZ1-GNZ2, the mineralization is located mostly in the upper part of GNZ1. Pd/Pt ratio is 1.5-2.5. The main ore object of zone $\mathrm{B}$ is the East Chuarvy PGE deposit, other ore occurrences are Sungjok, Chuarvy, and Bezymyanny. 
In the Sungjok, PGE mineralization was traced for more than $3 \mathrm{~km}$ along strike in elluvial boulders, and confirmed with drilling only in the central part of the occurrence. PGE mineralized rocks contain $0.5-2$ vol. \% sulphides, mainly pyrrhotite and chalcopyrite, the latter makes $25-50 \%$ of sulfide mass. The mineralized specimens collected in the outcrops, contain $\mathrm{Pt}+\mathrm{Pd}+\mathrm{Au} 7.0 \mathrm{~g} / \mathrm{t}$ on the average, $\mathrm{Pd} / \mathrm{Pt}=2.41$. The most rich samples with $\mathrm{Pt}+\mathrm{Pd}+\mathrm{Au}>21 \mathrm{~g} / \mathrm{t}$ were collected not in the area with drillholes, but to the east and to the west from it. In the drillholes ore zone thickness varies from 0.7 (in case of one ore body) to $44 \mathrm{~m}$ (three ore bodies with Pt $0.89-1.94 \mathrm{~g} / \mathrm{t}, 1.14$ on the average, and Pd $1-2.6 \mathrm{~g} / \mathrm{t}, 1.64 \mathrm{~g} / \mathrm{t}$ on the average. The ore zones dipping is $75^{\circ}$.

In the Chuarvy occurrence PGE zone B includes two mineralized levels, one of them below the GNZ1-GNZ2 boundary, another one above it. The mineralization is very changeable along strike. Due to the phenomenon of magmatic erosion, GNZ2 contacts different rocks of GNZ1, and in the areas, where GNZ2 contacts the olivine horizon, thickness of the ore body and PGE content increase significantly. If GNZ2 contacts the rocks below the olivine horizon in GNZ1, mineralization is absent. Content of sulfides is $0.5-1 \%$, pyrrhotite and chalcopyrite prevail, with ratio 70/30. The best section in the lower level is $1.5 \mathrm{~m}$ thick, $\mathrm{Pt}$ 0.89-2.13 g/t, Pd $1.12-5.12 \mathrm{~g} / \mathrm{t}$, and in the upper level is $0.8 \mathrm{~m}$ thick, Pt 10.81 and $\mathrm{Pd} 13.5 \mathrm{~g} / \mathrm{t}$.

The East Chuarvy deposit is the biggest ore object in zone B. The deposit consists of the Main Ore Body and 9 minor lenses. The main ore body was traced for $1200 \mathrm{~m}$ along strike and to the depth of $500 \mathrm{~m}$. It is conformal to general layering of the intrusion, and dips at an angle of $70^{\circ}$. The ore body is of complicated form, with thinnings and bulges. Inner structure is not homogenous due to irregular alternation of mineralized and not mineralized rocks.

No clear petrographical control was defined. Mineralization morphology is irregular sulfide and sulfide-oxide dissemination, rarely - veinlet-disseminated mineralization. The main sulfides are pyrrhotite, chalcopyrite, and pentlandite, sulfide content is 0.6 mas. \% on the average. Precious metals content is Pt $2.43 \mathrm{~g} / \mathrm{t}, \mathrm{Pd} 5.17 \mathrm{~g} / \mathrm{t}$, Au $0.29 \mathrm{~g} / \mathrm{t}$ (Ward et al., 2008).

Two levels of PGE mineralization were found in the Bezymyanny occurrence. The upper one is, in fact, the eastern continuation of the East Chuarvy Main Ore Body. PGE mineralization is controlled by GNZ1-GNZ2 boundary and located mainly below it in melanocratic gabbronorite-pyroxenite. The rocks contain about 1 vol.\% of sulfides, and chalcopyrite makes about $50 \%$ of sulfides. PGE mineralization forms one ore body up to $8.6 \mathrm{~m}$ thick with $1.80 \mathrm{~g} / \mathrm{t} \mathrm{Pt}$ and $2.68 \mathrm{~g} / \mathrm{t} \mathrm{Pd}$.

The lower mineralized level is located $50-100 \mathrm{~m}$ below the GNZ1-GNZ2 boundary in the horizon of taxytic gabbronorites, including those melanocratic and olivine-bearing. The horizon was crossed by drillholes, the rocks contain Pt $0.30 \mathrm{~g} / \mathrm{t}, \mathrm{Pd} 0.97 \mathrm{~g} / \mathrm{t}$, thickness of the mineralized interval is $1.85 \mathrm{~m}$. Pd/Pt ration varies from 3 to 4 . Geological position of this mineralization, petrography of the mineralized rocks, geochemical characteristics differ from those in zones A and B, this is another zone, not defined in the ore occurrences in the western part of the intrusion. The horizon of taxytic gabbronorite in the same geological position in the East Chuarvy deposit and in the Chuarvy occurrence is slightly enriched in PGE, but is not considered as an ore. In the eastern part of the intrusion, this horizon is more important, and, probably, it hosts PGE mineralization in the ore occurrences Predgorny and Chorozersky.

\subsection{Mineralized zone $C$}

Mineralized zone C is controlled by the boundary GNZ2-GZ1. Mineralized rocks of this zone were found in outcrops only in the western part of the intrusion in the Sungjok and Chuarvy blocks. Two drillholes crossed poor precious metal mineralization of zone $\mathrm{C}$ in the Sungjok occurrence, and in the Chuarvy it is not confirmed by drilling. This mineralization is of specific character: the mineralized rocks has very low sulfide content (or even do not contain sulfides), 
$\mathrm{Pd} / \mathrm{Pt}$ ratio is less than 1, and gold content is high (up to $2.2 \mathrm{~g} / \mathrm{t}$ in some specimens from the outcrops).

\section{Discussion and conclusions}

Three PGE mineralized zones are defined in the western and central parts of the East Pansky intrusion, the zones are controlled by the boundaries of magmatic layers. Similar stratigraphic control of PGE mineralization, connected with inflow of new portions of magmatic melt in the intrusive camera, is known in many layered intrusions in the world, for example, in Stillwater (the USA), Pennikat (Finland), Olanga group of intrusions (Northern Karelia).

Each mineralized zone in the East Pansky intrusion is a complicated geological body, consisting of two or more mineralized levels. These levels are most often connected with the upper or lower contacts of the olivine horizons, but in some cases move away for dozens meters. Mineralization is not continuous along strike and dip, and PGE rich rocks alternate with nonmineralized in the neighbouring drillholes. PGE content correlate with $\mathrm{S}$, but high content of sulphides does not guarantee high PGE.

Composition and geochemical characteristics of mineralization change along the cross section of the intrusion. Content of sulphide mineralization is relatively high in the lowermost zone $\mathrm{A}$, intermediate in the intermediate zone $\mathrm{B}$, and close to zero in the upper zone $\mathrm{C}$. $\mathrm{Pd} / \mathrm{Pt}$ ratio changes in the same direction from 5-6 in zone A to $1.5-2.5$ in zone B and to $<1$ in zone C. The reason for this tendency is not clear now, some additional investigation is needed. But, for example, we do not see similar tendency in the Pennicat intrusion.

In the western part of the East Pansky intrusion we see three PGE-mineralized zones A, $\mathrm{B}$, and $\mathrm{C}$, in the central part (East Chuarvy block) we have two zones $\mathrm{A}$ and $\mathrm{B}$. In the Bezymyanny one of two defined mineralized levels correlates with zone $\mathrm{B}$, and another one is connected with taxytic garronorite horizon, which is only slightly enriched in PGE in the East Chuarvy and Chuarvy. This mineralization is located in between $\mathrm{A}$ and $\mathrm{B}$ zones, and its characteristics (content of sulphides and $\mathrm{Pd} / \mathrm{Pt}$ ratio) are at intermediate position between $\mathrm{A}$ and B too. This mineralized level probably is the main one in the eastern part of the intrusion (the Predgorny and Churozersky).

Increase of price for PGE, most notably for Pd, may raise interest to the mineralized zone A, especially in the Chuarvy occurrence, where this zone is continuous and with stable high Pd content.

\section{Acknowledgements}

The author thanks his colleagues (in 2004-2009) from KMGC Oleg Kazanov and Vladimir Voitekhovich for fruitful joint work and discussion of the results. The present article was prepared with financial support of Project KO5125 ARLIN Arctic Layered Intrusions as a Source of Critical Metals for Green Economy.

\section{References:}

Kazanov O.V., Kalinin A.A. The structure and PGE mineralization of the East Pansky layered massif. The neighbourhood cooperation and experience exchange of geological prospecting and survey of PGE deposits in the Northern Fennoscandia. Apatity, KSC RAS, 2008, 56-67.

Kazanov O.V., Kalinin A.A. Geological-genetic model of low sulphide PGE deposit East Chuarvy and its application to prospecting in the East Pansly massif (Kola Peninsula). Ores and metals, 2011(3-4), 78

Ward M.A., McLaughlin D., Kalinin A.A., Voitekhovich V.S. Kola Mining Geological Company Ltd (KMGC) prospecting for PGE in the eastern part of Pansky Tundra area. The neighbourhood cooperation and experience exchange of geological prospecting and survey of PGE deposits in the Northern Fennoscandia. Apatity, KSC RAS, 2008, 52-55. 